Examining the Effectiveness of Technology use in Classrooms: A Tertiary Meta-Analysis

\author{
Karin Archer \\ Wilfrid Laurier University \\ Robert Savage \\ McGill University \\ Sukhbinder Sanghera-Sidhu \\ McGill University \\ Eileen Wood \\ Wilfrid Laurier University \\ Alexandra Gottardo \\ Wilfrid Laurier University \\ Victoria Chen \\ McGill University
}




\begin{abstract}
Identifying effective literacy instruction programs has been a focal point for governments, educators and parents over the last few decades (Ontario Ministry of Education, 2004, 2006; Council of Ontario Directors of Education, 2011). Given the increasing use of computer technologies in the classroom and in the home, a variety of information communication technology (ICT) interventions for learning have been introduced. Meta-analyses comparing the impact of these programs on learning, however, have yielded inconsistent findings (Andrews, Freeman, Hou, McGuinn, Robinson, \& Zhu, 2007; Slavin, Cheung, Groff, \& Lake, 2008; Slavin, Lake, Chambers, Cheung, \& Davis, 2009; Torgerson \& Zhu, 2003). The present tertiary meta-analytic review reassesses outcomes presented in three previous meta-analyses, while taking into account instructional variables, specifically training and support, and implementation fidelity, which can significantly impact learning outcomes. When training and support were entered as a moderator variable the traditional small overall effectiveness of the ICTs $(E S=0.18)$ increased significantly $(E S=.57)$. These findings indicate the importance of including implementation factors such as training and support, when considering the relative effectiveness of 1 ICT interventions.
\end{abstract}

Keywords: elementary education; evaluation of CAL systems; improving classroom teaching; media in education; pedagogical issues 


\section{A Tertiary Meta-Analysis of Studies Examining the Effectiveness of Technology use in Classrooms}

\section{Introduction}

Identifying effective literacy instruction programs has been a focal point for governments, educators and parents over the last few decades (Ontario Ministry of Education, 2004, 2006; Council of Ontario Directors of Education, 2011). Given the increasing use of computer technologies in the classroom and in the home, a variety of information communication technology (ICT) interventions for learning have been introduced. The variation across studies in factors such as sample size, types of ICT employed, and design of the study, however, make it difficult to reach clear conclusions about the overall effectiveness of these literacy based ICTs. Indeed, meta-analyses have generally been unable find a consistent positive effect for the use of ICTs in the classroom (Andrews, Freeman, Hou, McGuinn, Robinson, \& Zhu, 2007; Kulik, 2003; Slavin, Cheung, Groff, \& Lake, 2008; Slavin, Lake, Chambers, Cheung, \& Davis, 2009; Torgerson \& Zhu, 2003). The lack of a clear, consistent definition of ICT makes the task of investigating the effects of ICT even more challenging (Andrews et al., 2007). Further research is needed to explore other factors that may be contributing to the inability to assess the effectiveness of ICT in education.

\subsection{Previous Meta-Analyses}

Slavin and colleagues (2008) assessed the use of computer-assisted instruction (CAI) on reading in middle and high school students. Eight studies met the inclusion criteria. Slavin and colleagues (2008) reported a mean effect size of +0.10 and concluded 
"Also consistent with previous research is the finding in the present study that forms of CAI generally produced small effects.” (p. 309). Slavin and colleagues (2009) found similar results concluding "the evidence summarized here clearly indicates that the types of supplementary CAI programs that have dominated the use of technology in education for 30 years are not producing significant effects in upper elementary reading." (p. 1434).

Torgerson and Zhu (2003) conducted a meta-analysis on the use of ICT in English literacy learning. Of the 20 included studies they found only four studies to be statistically significant, with 1 of these having a negative effect size. Torgerson and Zhu (2003) stated "These data would suggest that there is little evidence to support widespread use of ICT in literacy learning in English.” (p. 52).

Andrews and colleagues (2007) examined whether information and communication technologies were effective in teaching English. They found that the studies were too heterogeneous, in both the written composition and the ICTs used, to conduct a meta-analysis. They concluded that "we are thus unable to make confident comparisons between the effectiveness of different ICTs on learning in English for 5- to 16-year-olds.” (p. 334).

Results from previous meta-analyses show very little evidence in support of ICT for literacy interventions. There is so much variation in the types of ICT interventions such as the technology used and the software programs used. Additionally, there is no clear definition or description of what constitutes an ICT intervention, it stands to reason that implementation of such studies needs to be further investigated to see if there are features of the implementation process that make them more or less effective. 


\subsection{Possible Factors}

Tamim and colleagues (2011) suggested that rather than the nature of the technology intervention, other factors such as pedagogy, teacher effectivenss, subject matter and fidelity of implementation may have a greater impact on effect size. In their second-order meta-analysis they validated the approach of synthesizing effect sizes as an appropriate method to use when examining potential factors contributing to the effectiveness of technology in learning (Tamim, Bernard, Borokhovski, Abrami, \& Schmid, 2011). Results from their second-order meta-analyses yeilded two important outocmes. First, their analyses support the potency of ICT interventions as a valuable instructional tool and second, they highlighted the importance of considering potential contributing factors when assessing ICT studies.

Two important factors that could be contributing to the effectiveness of ICT interventions, suggested by Savage and colleagues (2013), are the training and support that the teacher receives in delivery of the intervention, and the fidelity of implementation. Studies vary in the training and support that teachers receive during and prior to implementation. In many cases training may involve only a single session leaving teachers feeling unprepared (Anderson, Wood, Piquette-Tomei, Savage, \& Mueller, 2011). A recent study revealed not only the importance of proper training and support during initial implementation of an ICT intervention, but also the need for ongoing support throughout the intervention, especially when technology is involved (Anderson et al., 2011). In addition to training and support, implementation fidelity can also have an impact on the success of an intervention. Research shows that high fidelity of implementation can significantly increase the potential effectiveness of literacy programs 
(Davidson, Fields, \& Yang, 2009). Also important to note is that training and support, and implementation fidelity are closely linked and that the more training and support that is offered the higher implementation fidelity is likely to be. One other closely related factor that should also be considered is whether the implementation is delivered by a teacher or by a reseracher. It is essential to consider how these factors may have contributed to the outcomes obtained in previous systematic reviews of ICT based intervention studies.

1.3 Implementation. Despite general agreement regarding its importance, the reporting of implementation fidelity in studies is quite low and can have a significant impact on the outcome (McIntyre, Gresham, DiGennaro, \& Reed, 2007). Research has shown that technology integration in education can be influenced by a number of different factors. For example, Wozney and colleagues (2006) found that teaching styles, personal computer use, and technology-related training all played a role in how much technology was being used in the classroom, as well as how it was being used. Similarly Mueller and colleagues (2008) found experience with and attitude towards technology a major factor in classroom integration. It can be expected that the implementation of a technology-based intervention might be similarly influenced by a teacher's comfort, attitude and use of computers. Many ICT studies do not measure or account for fidelity of implementation, which may have a significant impact on the effectiveness of the intervention, especially in situations where the regular classroom teacher is employing the intervention (Campuzano, Dynarski, Agodini, Rall, \& Pendleton, 2009; Macaruso, Hook, \& McCabe, 2006; Ross, Nunnery, Avis \& Borek, 2005). Therefore, one important step is to measure and take into consideration implementation fidelity of an intervention 
in order to account for differences in how the intervention was delivered. Furthermore, when designing technology-based interventions another important component should be to increase implementation fidelity by increasing teachers' comfort and use of the technology. The logical way to do this is to offer the necessary training and support to the teachers.

1.4 Training and support. Because comfort with technology is an important predictor of the integration of technology it is essential to provide teachers with appropriate training and support prior to and during the use of technology in the classroom (Wood, Mueller, Willoughby, Specht \& DeYoung, 2005). While training may provide knowledge, it is vital to provide ongoing support until the teacher is comfortable with using the technology in the classroom.

ICT studies in the past have often provided very little if any information on training prior to implementation and when there is mention of training, it is often a oneday type training session (Campuzano et al., 2009; Jones, 1994; Ross, Nunnery, Avis, \& Borek, 2005). Furthermore, in many cases no ongoing support is provided, increasing the likelihood that the teacher is not comfortable with implementing the intervention.

The need for training and ongoing support is especially prevalent in ICT interventions due to the additional variables introduced through often unfamiliar, constantly evolving technology. Anderson and colleagues (2011) found that when implementing a computer-based reading intervention in the classroom, over $84 \%$ of support requests revolved around computer hardware and software issues. When constant support was available for the duration of the implementation the support requests made 
decreased over time (Anderson et al., 2011). This illustrates the need for on-going support, especially during initial stages of implementation.

\subsection{Teacher-delivered versus researcher-delivered interventions. One other} factor that may contribute to implementation fidelity is whether the intervention is delivered by a teacher or by a researcher. Research shows that effectiveness of interventions is consistently higher when delivered by a researcher rather than a teacher (Kim, Linan-Thompson, \& Misquitta, 2012).

Variations in implementation of technology-based interventions may be the reason for the inconsistent findings in the effectiveness of these types of interventions. Contrary to previous findings more recent research has shown that when proper training and support are provided, the significant benefits of ICT can be seen (Anderson et al., 2011). Therefore improving training and ongoing support when employing technologybased interventions could be an important first step in increasing implementation fidelity. It is also important to measure the fidelity of the implementation and to take this into consideration when analyzing the effectiveness of an intervention.

\subsection{Research Questions}

This review will reevaluate the implementation and outcome of previous ICT based studies by examining the two key variables: (1) the reported quality of the training and support teachers received for the implementation of the intervention and (2) the reported quality of implementation fidelity. The impact on effect size of teacher-delivered interventions versus researcher-delivered interventions will also be explored. Finally, 
reviews will be contrasted to examine if the studies selected from different systematic reviews show different patterns.

\section{Method}

\subsection{Study Selection}

At the outset, four prominent systematic reviews involving computer-based information and communication technologies for literacy instruction were selected for inclusion in this meta-analysis (Andrews, et al., 2007; Slavin, et al., 2008; Slavin, et al., 2009; Torgerson \& Zhu, 2003). These reviews were selected because they used comparable review criteria: control groups, study duration, and valid achievement measures. One review, Andrews and colleagues (2007), was subsequently excluded because necessary statistical information (e.g., specific effect sizes, means or mean scores) was not provided in the review.

Of the remaining three review papers, Torgerson and Zhu (2003) examined studies conducted between 1990 and 2002 that examined the impact of ICT on literacy learning for learners aged 5-16 years of age. Slavin and colleagues (2008) reviewed literacy studies using computer-assisted instruction for students in middle and high school between 1970 and 2007. The review by Slavin and colleagues (2009) examined students in kindergarten through grade 5 between 1970 and 2007. All of the reviews reported substantial variation in effect sizes across studies and overall, minimal evidence of ICT effectiveness.

The present meta-analyses included all articles that could be retrieved from the original three reviews above. Specifically, Slavin and colleagues (2008) included 8 articles in their review of computer-assisted instruction. Of the 8 articles 6 were located, 
however, despite diligent searching, 2 were not available and were therefore excluded. One of the excluded articles was a research report and one was a dissertation (Metrics Associates, 1981; Roy, 1993, respectively).

Slavin and colleagues (2009) included 10 articles in their review of instructional technology in beginning reading. Nine of 10 articles was included while 1 research project was not available and was therefore excluded (RMC, 2004). Of the remaining 9 articles, 1 reported 4 sub-studies (Campuzano et al., 2009). Consistent with Slavin and colleagues (2009) the 4 sub-studies were retained as individual studies in the current review. Therefore, 12 studies from Slavin and colleagues (2009) were included in the current analyses.

Torgerson and Zhu (2003) included 12 articles. Eight of these articles included 2 sub-studies each. Consistent with Torgerson and Zhu (2003) the sub-studies were maintained separately in the current analyses. Therefore, 20 studies from Torgerson and Zhu (2003) were included in the current analysis.

In total 38 studies computer-based information and communication technologies studies from the 3 previous reviews were included in the current review (see Appendix A for a brief summary of included studies).

Articles from the three reviews did not overlap. Slavin et al. (2008) and Slavin et al. (2009) conducted reviews on different age groups. Slight variations in the search procedures as well as inclusion/exclusion process might account for the lack of overlap in articles between the Slavin reviews and the Torgerson review. For example, Torgerson and Zhu (2003) selected only studies with randomized control trials while Slavin et al. $(2008,2009)$ required a control group but not necessarily random assignment. On the 
other hand Slavin et al. $(2008,2009)$ had other specific requirements such as requiring at least 2 teachers and 15 students in each treatment group and excluded studies with measures inherent to the treatment group and not the control group. Slavin et al. (2008, 2009) also allowed for a variety of articles such as dissertations, while Torgerson and Zhu (2003) excluded formats such as editorials, policy documents, non-systematic reviews, non-evaluated interventions and dissertations.

\subsection{Evaluating Training/Support and Implementation Fidelity}

Two overall evaluation scores were generated for each of the 38 studies. These overall evaluation scores were used in the subsequent analyses One score provided an overall evaluation of the training and support provided in the original study and the second measure provided an overall evaluation of the implementation fidelity. Each of these summary evaluations employed a 4-point scale where $0=$ Not Present, 1=Mentioned but NO Information on How, 2=Mentioned with Limited Detail, and 3=Mentioned with Enough Detail to Roughly Replicate. These overall evaluations were derived from a more comprehensive scoring tool which employed both qualitative and quantitative measures. The scoring tool is described in more detail below.

The 20-item scoring tool assessed: Training and Support (5 questions), Intervention Implementation (3 questions), Implementation Fidelity Process (4 questions), Implementation Fidelity Measurement Tool (4 questions), and Implementation Results (4 questions). Questions used a $0=N o$ and $1=Y e s$ scoring scheme, a 4-point scale where $0=$ Not Present, $1=$ Mentioned but NO Information on How, 2=Mentioned with Limited Detail, and 3=Mentioned with Enough Detail to Roughly 
Replicate and descriptive information to support the score given and to clarify any unique or additional information not covered by the 20 questions.

2.3.1 Training/support. The first three questions assessed whether or not training was reported, in how much detail it was described and whether or not it was a 'one-shot' training session. Two questions assessed whether on-going support was reported and in how much detail the support was described.

2.3.2 Fidelity. The second section of the scoring tool was comprised of four subsections. The first of which assessed the intervention implementation through 3 questions investigating whether the classroom teacher delivered the intervention, and when and how often the participants received in the intervention. Descriptive information was also obtained to identify all persons who provided the intervention (e.g., other than the classroom teacher, paraprofessionals, graduate students etc.). The second subsection employed 4 questions to assess the process of ensuring fidelity. Specifically, whether or not implementation fidelity was measured, in how much detail it was reported, how the observers were trained and how often observations were conducted. The third subsection assessed the implementation fidelity measurement tool that was used in each study. The four questions in this section investigated whether an implementation fidelity measurement tool was used, if there was an explanation of how the implementation fidelity measurement tool corresponded to the intervention, if the data was collected by two or more raters and if inter-rater reliability was reported. The final subsection for fidelity assessed whether the results of the measured implementation was reported, if statistical analyses were used to determine the effectiveness of the interventions, if the 
impact of the implementation fidelity was discussed and whether or not different levels of implementation were considered in the final student outcomes.

The scoring tool provided a comprehensive summary of support/training and fidelity considerations for each article. Based on the findings of the scoring tool, the overall summary score for training/support and fidelity were assigned.

\subsection{Procedure}

Development of the scoring rubrics began with the construction of the criteria to be included in the scoring tool. The particular elements were derived collaboratively by three raters who reviewed theoretical and empirical work related to instruction, interventions and technology. The three raters then used the scoring tool to independently assess three intervention studies (not part of this meta analysis). Inter-reliability among the three raters was $93.35 \%$.

The 38 articles from the reviews included in the present meta-analysis were scored independently by two raters, one of which was not involved in the development of the scoring tool. The raters then discussed their scoring information. Following discussion, the two raters independently assigned the overall training/support score and the overall fidelity score for each of the 38 articles. Inter-rater reliability for the overall implementation training and support score was $92.9 \%$. Inter-rater reliability for the overall implementation fidelity score was $85.7 \%$. Disagreements were resolved through discussion.

The effect size, sample size of the treatment group, and sample size of the control group reported in each review were recorded. These measures were used in subsequent analyses. 


\section{Results}

\subsection{Overall Results}

A re-analysis of the 38 studies was conducted after converting all effective size measures to a common measure. Slavin and colleagues $(2008,2009)$ reported standardized mean difference scores for effect size, while Torgerson and Zhu (2003) reported Hedges g' scores. Software was used to transform all effect size scores into Hedges' g (Comprehensive Meta-Analysis, $\underline{w w w . m e t a-a n a l y s i s . c o m})$. The re-analysis of effect sizes using Hedges' g were conducted using the random effects model. Of the 38 studies 8 had negative effects sizes and 30 had positive effect sizes. Of the 8 negative effect sizes one was statistically significant. Of the 30 positive effect sizes 10 were statistically significant (See Table 1 for complete results). Using Cohen's (1988) definition of effect sizes, the overall effect size for all studies included together was small $0.181(C I=0.105$ to 0.256$)$ with a standard error of .039 (Cohen,1988). Cohen (1988) defined effect sizes of .2 to be small, .5 to be moderate, and .8 to be large. The studies were heterogeneous $(Q=114.756, d f=37, p<0.001)$. In the studies $67.76 \%$ of the variance was due to between studies variance $\left(T^{2}=0.021\right)$. Examination of the individual studies as a function of the original review in which they were presented yielded effect sizes that ranged from Cohen's (1988) definition of a small effect size (i.e., 0.010 ) to very large effect sizes (i.e., effect sizes of 1.30 to 2.74 ) as defined by Rosenthal (1996). Specifically, of the 6 studies from the Slavin (2008) systematic review, 4 had very small effect sizes (Chaing, 1978; Liston, 1991; Ross \& Nunnery, 2005; Ross et al., 2005) with 2 of these being statistically significant (Liston, 1991, Ross \& Nunnery, 2005)(ES = $0.060, p=0.042 ; E S=0.130, p<0.001)$. One study had a small to moderate effect size 
(Hunter, 1994) which was statistically significant $(E S=0.309, p=0.011)$ and one study had a moderate effect size (Hagerman, 2003) which was also statistically significant (ES $=0.527, p=0.004)$. See Table 1 for complete results.

Of the 12 studies from the Slavin (2009) systematic review, 5 had very small effect sizes (Campuzano et al., 2009; Chambers et al., 2006) none of which were statistically significant. Five studies had small effect sizes (Abraham, 1984, Beasley, 1989; Chambers et al., 2008; Collis et al., 1990; Marcaruso et al., 2006) none of which were statistically significant. One study had a statistically significant moderate to large effect size (Cassidy \& Smith, 2005) $(E S=0.704, p=0.001)$ and another study had a large to very large effect size which was also statistically significant (Erdner et al., 1998) $(E S=1.040, p<0.001)$. See Table 1 for complete results.

Of the 20 studies from the Torgerson and Zhu (2003) systematic review, 5 studies had very small effect sizes (Beringer et al., 1998; Golden et al., 1990; Jinkerson \& Baggett, 1993; Lin et al., 1991; Reinking \& Rickman, 1990) none of which were statistically significant. One study had a small effect size (Swanson \& Trahan, 1992) which was not statistically significant. Five studies had small to moderate effect sizes (Beringer et al., 1998; Jones, 1994; Matthew, 1996; McArthur et al., 1990; Lin et al., 1991) none of which were statistically significant. Two studies had moderate effect sizes (Heise et al., 1991; Matthew, 1996) one of which was statistically significant (Matthew, 1996) ( $E S=0.545, p=0.020$ ). Four studies had moderate to large effect sizes (Golden $e t$ al., 1990; Mitchell \& Fox, 2001; Swanson \& Trahan, 1992; Zhang \& Brooks, 1995) only one of which was statistically significant (Mitchell \& Fox, 2001) but also had a negative effect size $(E S=-0.604, p=0.038)$. Two studies had large to very large effect sizes 
(Jones, 1994; Reinking \& Rickman, 1990) both of which were statistically significant (ES $=1.251, p=0.008 ; E S=0.925, p=0.001)$. Finally, one study had a very large effect size (Zhang \& Brooks, 1995) which was also statistically significant ( $E S=2.740, p<$ 0.001). See Table 1 for complete results.

\subsection{Moderator Variables}

Four moderator variables assessed effect sizes in respect to:

1. The systematic review from which they were retrieved.

2. The overall training and support score.

3. The overall implementation fidelity score.

4. Who delivered the intervention (teacher versus researcher).

For a complete itemization of the moderator variables see Table 2.

\subsubsection{The systematic review from which the studies were retrieved. No} significant difference was found in effect sizes between the studies from Slavin (2008) $(E S=0.156, S E=0.073)$, Slavin $(2009)(E S=0.169, S E=0.059)$ and Torgerson and Zhu (2009) $(E S=0.242, S E=0.079)(Q=0.757, d f=2, p=0.685)$.

3.2.2 The overall training and support score. Twenty-one studies received a score of 0 (Not Present) for training and support, 6 were rated 1 (Mentioned but no Information on How), 5 were rated 2 (Mentioned with Limited Detail) and 6 were rated 3 (Mentioned with Enough Detail to Roughly Replicate). Effect sizes differed as a function of the training and support evaluation score $(Q=14.899, d f=3, p=0.002)$ (Post hoc Tukey $\mathrm{b}$ comparisons indicated that the group of studies rated 2 (Mentioned with Limited Detail; $E S=0.573, S E=0.120$ ) for training and support had a significantly higher effect sizes than the groups of studies rated 0 (Not Present; $E S=0.187, S E=0.059), 1$ 
(Mentioned but no Information on How; $E S=0.175, S E=0.089$ )), and 3 (Mentioned with Enough Detail to Roughly Replicate; $E S=0.031, S E=0.072)$. There were no differences in effect sizes between studies rated 0,1 , and 3 for training and support.

3.3.3 The overall implementation fidelity score. Twenty-six studies were given an overall implementation fidelity score of 0 (Not Present; $E S=0.185, S E=0.051), 10$ were rated 1 (Mentioned but no Information on How; $E S=0.188, S E=0.066$ ), 2 were rated 2 (Mentioned with Limited Detail; $E S=0.133, S E=0.229$ ) and no studies were rated 3 (Mentioned with Enough Detail to Roughly Replicate). There were no significant differences as a function of implementation fidelity $(Q=0.054, d f=2, p=0.973)$.

\subsubsection{Who delivered the intervention (teacher versus researcher). Of the 38}

studies, researchers were reported to have implemented the intervention in 11 of the studies and 27 were reported as implemented by teachers. No significant difference in effect size was found as a function of the researchers $(E S=0.165, S E=0.102)$ or teachers $(E S=0.185, S E=0.042)$ delivering the intervention programs $(Q=0.032, d f=$ $1, p=0.858)$.

\subsection{Publication Bias}

A funnel plot was created to examine possible publication bias. Effect size was placed on the $\mathrm{x}$-axis and sample size was placed on the y-axis. Studies included made a fairly symmetrical funnel (see Figure 1). The existence of a publication bias is therefore unlikely.

\subsection{Training and Support and Implementation Fidelity}


A Pearson's correlation was conducted to assess the association between training/support and implementation fidelity. There was a strong positive correlation between training/support, and implementation fidelity $(r=.613, n=38, p<.001)$.

Given that many studies received a score of zero for both training/support and implementation fidelity, which may have inflated the overall correlation, a further exploratory analysis was conducted with only the studies that had scores where these elements were present in the research. When studies were assessed based on descriptions of these two key variables a strong negative correlation between training/support, and implementation fidelity resulted $(r=-.653, n=12, p=.021)$.

\section{Discussion}

The present tertiary meta-analysis provides insight for two key issues. First, the present study provides a foundation for understanding inconsistent outcomes among preexisting ICT literacy intervention meta-analyses. Second, the present study provides evidence of the importance of understanding the context through which ICT interventions are delivered. Specifically, two key instructional implementation considerations, the training and support of those conducting interventions and attention to the fidelity of the intervention program, contribute to successful outcomes.

Consistent with the previous systematic reviews, the overall effect size for literacy-based ICT interventions in the present study was positive but small (Slavin et al., 2008; Slavin et al., 2009; Torgerson \& Zhu, 2003). Interestingly, there were individual studies that yielded learning gains and those that did not. Specifically, 8 of the 38 studies had negative effect sizes, implying that, in these instances, the instructional intervention may actually have been harmful to learning. In addition, 3 studies yielded moderate to 
large effect sizes but, unexpectedly, were not statistically significant contributors to learning gains (Golden et al., 1990; Swanson \& Trahan, 1992; Zhang \& Brooks, 1995). In these latter studies the small sample may have been a contributing factor to the lack of statistical significance. Most important, however, the variability in outcomes from individual studies provides an important marker that individual differences in the design or execution of the intervention may be critical for ensuring effective instruction when using ICT.

Provision of training and support for those delivering the intervention, for example, was a design feature that positively impacted the effect of the intervention. When examining training and support it was clear that studies that mentioned training and support with some detail showed moderate effect sizes, which were significantly higher than studies where little or no detail about training and support was mentioned. Although it may appear intuitive that training and support needs to be a salient component for delivering an effective intervention program, the lack of mention of this design aspect in more than $55 \%$ of the studies sampled here suggests that training and instruction needs to be a greater focal point in design. Appropriate training of educators, especially with technology-based instructional programs, has been shown to increase knowledge, and reduce anxiety (Wood et al., 2005). Increased comfort with such technologies and instructional programs can also impact educator's integration of technology within their classroom (Mueller et al., 2008). Ongoing support is also critical as it provides educators with opportunity to gain further expertise and skills as well as to problem-solve challenges that may have been unanticipated in a preliminary training session (Anderson et al., 2011). Attention to training and ongoing support, therefore, can 
impact the effectiveness of ICT interventions at the outset and throughout the duration of the intervention. In addition, high quality support may also influence educators decisions to continue to use the intervention in an ongoing way after participating in any given research study. What was unexpected in the outcomes of the present study was that only the studies with the second highest ratings for training and support provided the learning advantages, those studies with the highest teaching and support ratings did not differ from those with less or no training and support. One interesting observation was that 4 of the 6 studies with the highest rating were part of a set of studies retrieved from one article (Campuzano et al., 2009). Each study individually produced a small positive effect on learning. These small gains along with the attention given to training and support suggest that some other feature of the instructional design, content, delivery or participant sample may be contributing to lower learning gains, and in turn, these may have contributed to the limited impact. Previous studies have noted that the Campuzano et al. (2009) cluster of studies, while large in scale and methodologically strong in some respects, reported no data on treatment integrity (see Savage et al., 2013). Of the other 2 studies with the highest training and support ratings both have atypicalities of possible importance. The Chiang (1978) study is the oldest study included and must therefore have involved technology dating back to the early or mid 1970s which is most likely not representative of more recent studies. This study also obtained a lower treatment fidelity rating (i.e., 1). The remaining study (Beasley, 1989) was an unpublished Ph.D. thesis. This thesis also reported no data whatsoever on treatment fidelity. Findings from these highest scoring studies for support and training demonstrate the negative correlation between training and implementation. Specifically, although considerable attention was devoted to training 
instructors in the intervention and providing support, little attention was dedicated to monitoring whether the instructors did indeed follow the intervention protocols. This oversight suggests that treatment fidelity needs to be assessed as stringently as instructional concerns.

Although implementation fidelity was expected to impact on the effect of the ICT intervention, this was not found in the present study. Instead, what was clear was that the vast majority of studies (68\%) failed to comment on any aspect involving fidelity. Given the comprehensive nature of the scoring tool which assessed multiple aspects of fidelity (from process to product), this absence of consideration in so many studies is a concern. Overall training and support, and implementation fidelity showed a strong positive correlation, however, when the 21 studies that reported no information on both factors were removed a strong negative correlation ensued. It is possible that in the remaining studies so much attention was placed on training and support that it came at a cost to implementation fidelity. Training and support without monitoring implementation fidelity may not be sufficient to ensure the success of instructional interventions. It may be the case that some ICT interventions appear to be self-explanatory or intact, however, even when the programs may be well designed and comprehensive, if the instructors do not provide opportunities for the full intervention to occur, even these well-designed programs will fail to provide an ideal instructional aid. More recent studies that have carefully undertaken and documented implementation fidelity and have provided training and just-in-time support have also been successful in showing significant increases in literacy through the use of ICT interventions (Anderson et al., 2011; Savage et al., 2013; Wolgemuth et al., 2011). Outcomes of the present study, and previous research 
(Anderson et al, 2011; Savage et al., 2013) suggest that considerable attention needs to be dedicated to both training and implementation.

Interestingly, differences in outcomes were not apparent when researchers or educators delivered the interventions. This finding differs from previous research where larger effect sizes were detected when researchers delivered an intervention in comparison to those delivered by teachers (National Reading Panel, 2000). An important difference between this previous and present research involves the platform used to deliver the instruction. In previous research individuals, researchers and educators delivered the interventions directly, whereas in the present study the software delivered the instruction facilitated by researchers and/or educators. It is possible that using high quality software ensures equivalence in instruction. The lack of differences when technology is employed suggests that the technology may compensate for some variability and limitations in those delivering the intervention.

In summary, this meta-analysis provides results that suggest that underlying factors in the implementation process of technology-based interventions may be contributing to the modest results found in the effectiveness of ICT studies generally. In particular, the role of training and support seems to influence effect sizes for technology on reading. Where training and support are undertaken fully and diligently, and reported in detail, our research suggests that the overall effect size of ICT is medium, and where not reported, it is small using conventional metrics. Thus despite the existence of several previous findings from meta-analyses suggesting limited effectiveness of ICT interventions, this review demonstrates that ICT interventions can prove to be more 
effective when implementation factors such as support and training are employed, measured, and clearly reported.

\section{Future Directions}

Given that the term "technology" now encompasses such a wide array of tools that it makes it difficult to define exactly what an ICT intervention should look like, it is even more important to attend to key variables that might moderate outcomes. Regardless of the type of technology employed, users need to be sure that they have the skills and knowledge necessary to use the technology effectively throughout the treatment trial and mechanisms must be in place to ensure that reliable, consistent implementation is achieved. 


\section{References}

Abram, S. L. (1984). Effect of computer assisted instruction on first grade phonics and mathematics achievement computation. Dissertation Abstracts International Part A: Humanities and [DISS. ABST. INT. PT. A-HUM. \& SOC. SCI.], 45(4), 78.

Anderson, A., Wood, E., Piquette-Tomei, N., Savage, R. S., \& Mueller, J. (2011) Evaluating the impacts of just-in-time instructional support for teachers introducing a web-based reading program for primary grade children. Journal of Technology and Teacher Education, 19(4), 499-525.

Andrews, R., Freeman, A., Hou, D., McGuinn, N., Robinson, A., \& Zhu, J. (2007). The effectiveness of information and communication technology on the learning of written English for 5 to 16 year olds. British Journal of Educational Technology, 38, 325-336. doi: 10.1111/j.1467-8535.2006.00628.x

Beasley, N. (1989). The effects of the IBM writing to read program on the achievement of selected first grade students. Dissertation Abstracts International, 51(3), 739A.

Berninger, V., Abbott, R., Rogan, L., Reed, E., Abbott, S., Brooks, A., Vaughan, K., \& Graham, S. (1998). Teaching spelling to children with specific learning disabilities: The mind's ear and eye beat the computer or pencil. Learning Disability Quarterly, 21, 106-122. Retrieved from http://www.jstor.org/stable/1511340

Campuzano, L., Dynarski, M., Agodini, R., \& Rall, K. (2009). Effectiveness of reading and mathematics software products: Findings from two student cohorts. NCEE 2009-4041. National Center for Education Evaluation and Regional Assistance, 1-111. Retrieved from http://ies.ed.gov/ncee/pubs/

Cassady, J. C., \& Smith, L. L. (2005). The impact of a structured integrated learning system on first-grade students' reading gains. Reading \& Writing Quarterly, 21, 361-376. doi: 10.1080/10573560591002277

Chambers, B., Cheung, A. C. K., Madden, N. A., Slavin, R. E., \& Gifford, R. (2006). Achievement effects of embedded multimedia in a success for all reading program. Journal of Educational Psychology, 98(1), 232-237. doi: 10.1037/00220663.98.1.232

Chambers, B., Slavin, R. E., Madden, N. A., Abrami, P. C., Tucker, B. J., Cheung, A., \& Gifford, R. (2008). Technology infusion in Success for All: Reading outcomes for first graders. Elementary School Journal, 109, 1-15. Retrieved from http://successforall.org/_images/pdfs/Technology_Infusion_11_04_05.doc

Chiang, A. (1978). Demonstration of the use of computer-assisted instruction with handicapped children. Final report (ERIC Document Reproduction Service No. ED166913). 
Cohen, J. (1988). Statistical power analysis for the behavioral sciences $\left(2^{\text {nd }} \mathrm{ed}.\right)$. Hillsdale, NJ: Erlbaum.

Collis, B., Ollila, L., \& Ollila, K. (1990). Writing to read: an evaluation of a Canadian installation of a computer-supported initial language environment. Educational Computer Research, 6, 411-427.

Council of Ontario Directors of Education (2011) Do I have to go Home Already? Retrieved from http://ontariodirectors.ca/Summer_Literacy/Summer_Literacy_Learning_Report.p df

Davidson, M.R., Fields, M. K., \& Yang, J. (2009) A randomized trial study of preschool literacy curriculum: The importance of implementation. Journal of Research on Educational Effectiveness, 2(3), 177-208. doi: 10.1080/19345740902770028

Erdner, R. A., Guy, R. F., \& Bush, A. (1998). The impact of a year of computer assisted instruction on the development of first grade learning skills. Journal of educational computing research, 18, 369-386. doi: 10.2190/V8RR-K7LF-DNNAHY8K

Golden, N., Gersten, R., \& Woodward, J. (1990). Effectiveness of guided practice during remedial reading instruction: An application of computer-managed instruction. Elementary School Journal, 90, 291-304. doi: 10.1086/461619

Hagerman, T. E. (2003). A quasi-experimental study on the effects of Accelerated Reader at middle school. Unpublished doctoral dissertation, University of Oregon, Eugene.

Heise, B. L. (1991). Building base vocabulary with computer-assisted instruction. Teacher Education Quarterly, 18, 55-63.

Hunter, C. T. L. (1994). A study of hte effect of instructional method on the reading and mathematics achievement of Chapter One students in rural Georgia. Unpublished doctoral dissertation, South Carolina State University, Orangeburg.

Jinkerson, L., \& Baggett, P. (1993). Spell checkers: Aids in identifying and correcting spelling errors. Journal of Computing in Childhood Education, 4, 291-306.

Jones, I. (1994). The effect of a word processor on the written composition of secondgrade pupils. Computers in the Schools, 11, 43-54. doi: 10.1300/J025v11n02_05

Kim, W., Linan-Thompson, S., \& Misquitta, R. (2012) Critical factors in reading comprehension instruction for students with learning disabilities: A research synthesis. Learning Disabilities Research \& Practice, 27(2), 66-78. 
Kulik, J. A. (2003). Effects of using instructional technology in elementary and secondary schools: What controlled evaluation studies say (SRI Project No. P10446.001). Arlington, VA: SRI International.

Lin, A. (1991). The effects of CAI on word recognition in mildly mentally handicapped and nonhandicapped learners. Journal of Special Education Technology, 11, 1625 .

Liston, W. R. (1991). The effects of computer-asisted instruction on remedial reading students' achievement in grade 10 identified South Carolina high schools as measured by BSAP state testing in school years 1988-89 and 1989-90.

Unpublished doctoral dissertation, University of South Carolina, Columbia.

MacArthur, C. A., Haynes, J. Q. A., Malouf, D. B., Harris, K., \& Owings, M. (1990). Computer assisted instruction with learning disabled students: Achievement, engagement, and other factors that influence achievement. Journal of Educational Computing Research, 6, 311-328.

Macaruso, P., Hook, P. E., \& McCabe, R. (2006). The efficacy of computer based supplementary phonics programs for advancing reading skills in at risk elementary students. Journal of Research in Reading, 29, 162-172. doi: 10.1111/j.1467-9817.2006.00282.x

Matthew, K. I. (1996). The impact of CD-ROM storybooks on children's reading comprehension and reading attitude. Journal of Educational Multimedia and Hypermedia, 5, 379-394.

McIntyre, L. L., Gresham, F. M., DiGennaro, F. D., \& Reed, D. D. (2007) Treament integrity of school-based interventions with children in the journal of applied behavioral analysis 1991-2005. Journal of Applied Behavior Analysis, 40(4), 659672.

Metrics Associates. (1981). Evaluation of the Computer Assisted Instruction Title I Project, 1980-81. Research report. Chelmsford, MA: Merrimack Education Center.

Mueller, J., Wood, E., Willoughby, T., Ross, C., \& Specht, J. (2008). Identifying discriminating variables between teachers who fully integrate computers and teachers with limited integration. Computers \& Education, 51, 1523-1537. doi:10.1016/j.compedu.2008.02.003

Mitchell, M. J., \& Fox, B. J. (2001). The effects of computer software for developing phonological awareness in low-progress readers. Literacy Research and Instruction, 40, 315-332. doi: 10.1080/19388070109558353

National Reading Panel (2000) Teaching children to read: An evidence-baed assessment of the scientific reasearch literature on reading and its implications for reading 
instruction. Retrieved from

https://www.nichd.nih.gov/publications/pubs/nrp/Documents/report.pdf

Ontario Ministry of Education (2004). Literacy for learning: The report of the expert panel on literacy in grades 4 to 6 in Ontario. Toronto, ON: Queen's Printer. Retrieved from http://www.edu.gov.on.ca/eng/document/reports/literacy/panel/literacy.pdf

Ontario Ministry of Education (2006). The Ontario curriculum, grades 1-8: language. Toronto, ON: Queen's Printer. Retrieved from http://www.edu.gov.on.ca/eng/curriculum/elementary/language18currb.pdf

Reinking, D., \& Rickman, S. S. (1990). The effects of computer-mediated texts on the vocabulary learning and comprehension of intermediate-grade readers. Journal of Literacy Research, 22, 395-411. doi: 10.1080/10862969009547720

RMC Research Corporation. (2003). The literacy center K-1 Las Vegas research project. Las Vegas, NV: Author. Las Vegas, NV: Author.

Rosenthal, J.A. (1996). Qualitative descriptors of strength of association and effect size. Journal of Social Service Research, 21(4), 37-59.

Ross, S. M., \& Nunnery, J. A. (2005). The effect of School Renaissance on student achievement in two Mississippi school districts. Memphis, TN: University of Memphis, Center for Research in Education Policy and Education Innovations (pp. 42).

Ross, S. M., Nunnery, J. A., Avis, A., \& Borek, T. (2005). The effects of School Renaissance on student achievement in two Mississippi school districts: A longitudinal quasi-experimental study. Memphis, TN: University of Memphis, Center for Research in Education Policy and Education Innovations (pp. 39).

Roy, J. W. (1993). An investigation of the efficacy of computer-assisted mathematics, reading, and language arts instruction. Ed. D. dissertation, Baylor University, United States--Texas. Retrieved from Dissertations \& Theses: Full Text. (Publication No. AAT 9323305).

Savage, R., Abrami, P. C., Piquette, N., Wood, E., Deleveaux, G., Sanghera-Sidhu, S. \& Burgos, G. (2013) A (Pan-Canadian) cluster randomized control effectiveness trial of the ABRACADABRA web-based literacy program. Journal of Educational Psychology, 105(2), 310-328.

Slavin, R. E., Cheung, A., Groff, C., \& Lake, C. (2008). Effective reading programs for middle and high schools: A best-evidence synthesis. Reading Research Quarterly, 43, 290-322. doi: 10.1598/RRQ.43.3.4 
Slavin, R. E., Lake, C., Chambers, B., Cheung, A., \& Davis, S. (2009). Effective reading programs for the elementary grades: A best-evidence synthesis. Review of Educational Research, 79, 1391. doi: 10.3102/0034654309341374

Statistics Canada (2008) Computers in the classroom: Opportunity and challenge. Retrieved from http://www.statcan.gc.ca/pub/81-004-x/200409/7017-eng.htm\#ref

Swanson, H. L., \& Trahan, M. F. (1992). Learning disabled readers' comprehension of computer mediated text: The influence of working memory, metacognition and attribution. Learning Disabilities Research \& Practice.

Tamim, R. M., Bernard, R. M., Borokhovski, E., Abrami, P. C., \& Schmid, R. F. (2011) What fourty years of research says about the impact of technology on learning: A second-order meta-analysis and validation study. Review of Educational Research, 81(1), 4-28. doi: 10.3102/0034654310393361

Torgerson, C. J., \& Zhu, D. (2003). A systematic review and meta-analysis of the effectiveness of ICT on literacy learning in English, 5-16. In R. Andrews (Ed.), The impact of ICT on literacy education. London: RoutledgeFalmer.

Wood, E., Mueller, J., Willoughby, T., Specht, J., \& Deyoung, T. (2005). Teachers' perceptions: Barriers and supports to using technology in the classroom. Education, Communication \& Information, 5(2), 183-206.

Wozney, L., Venkatesh, V., \& Abrami, P. (2006). Implementing computer technologies: Teachers' perceptions and practices. Journal of Technology and Teacher Education, 14, 173-207.

Zhang, Y. (1995). Quality of writing by elementary students with learning disabilities. Journal of Research on Computing in Education, 27, 483-499. 
Table 1

Effect Sizes, Confidence Intervals, Z-Values and p-values for all Studies

\begin{tabular}{|c|c|c|c|c|}
\hline Study name & $\begin{array}{l}\text { Hedges's } \\
\quad g\end{array}$ & $C I$ & Z-Value & $p$-Value \\
\hline Chiang (1978) & 0.139 & -0.167 to 0.892 & 0.892 & 0.373 \\
\hline Hagerman (2003) & 0.527 & 0.166 to 0.888 & 2.860 & $0.004 * *$ \\
\hline Hunter (1994) & 0.309 & 0.070 to 0.548 & 2.532 & $0.011^{*}$ \\
\hline Liston (1991) & 0.060 & 0.002 to 0.118 & 2.034 & $0.042 *$ \\
\hline Ross \& Nunnery (2005) & 0.130 & 0.058 to 0.202 & 3.516 & $0.000 * *$ \\
\hline $\begin{array}{l}\text { Ross, Nunnery, Avis \& Borek } \\
\text { (2005) }\end{array}$ & 0.030 & -0.032 to 0.092 & 0.942 & 0.346 \\
\hline Abraham (1984) & 0.189 & -0.196 to 0.573 & 0.962 & 0.336 \\
\hline Beasley (1989) & -0.267 & -0.724 to 0.190 & -1.146 & 0.252 \\
\hline $\begin{array}{l}\text { Campuzano, Dynarski, Agodini \& } \\
\text { Rall (2009) - A }\end{array}$ & 0.110 & -0.037 to 0.257 & 1.464 & 0.143 \\
\hline $\begin{array}{l}\text { Campuzano, Dynarski, Agodini \& } \\
\text { Rall (2009) - B }\end{array}$ & 0.010 & -0.110 to 0.129 & 0.164 & 0.870 \\
\hline $\begin{array}{l}\text { Campuzano, Dynarski, Agodini \& } \\
\text { Rall (2009) - C }\end{array}$ & 0.030 & -0.128 to 0.188 & 0.372 & 0.710 \\
\hline $\begin{array}{l}\text { Campuzano, Dynarski, Agodini \& } \\
\text { Rall (2009) - D }\end{array}$ & 0.020 & -0.097 to 0.137 & 0.333 & 0.739 \\
\hline Cassidy \& Smith (2005) & 0.704 & 0.288 to 1.120 & 3.320 & $0.001 * *$ \\
\hline $\begin{array}{l}\text { Chambers, Cheung, Madden, } \\
\text { Slaving \& Gifford (2006) } \\
\text { Chambers, Slavin, Madden, } \\
\text { Abrami, Tucker, Cheung \& Gifford } \\
(2008)\end{array}$ & 0.170 & -0.028 to 0.367 & 1.683 & 0.092 \\
\hline Collis, Ollila \& Ollila (1990) & 0.268 & -0.130 to 0.666 & 1.318 & 0.188 \\
\hline Erdner, Guy \& Bush (1998) & 1.040 & 0.590 to 1.491 & 4.531 & $0.000 * *$ \\
\hline Macaruso, Hook \& McCabe (2006) & 0.199 & -0.093 to 0.492 & 1.334 & 0.182 \\
\hline $\begin{array}{l}\text { Beringer, Abbott, Rogan, Reed, } \\
\text { Abbott, Brooks, Vaughan \& }\end{array}$ & -0.054 & -0.611 to 0.503 & -0.190 & 0.849 \\
\hline
\end{tabular}


Graham (1998) - A

Beringer, Abbott, Rogan, Reed, Abbott, Brooks, Vaughan \& Graham (1998) - B

Golden, Gersten \& Woodward, (1990) - A

Golden, Gersten \& Woodward, (1990) - B

Heise, Papalewis \& Tanner (1991)

Jinkerson \& Baggett (1993)

Jones (1994) - A

Jones (1994) - B

Lin, Podell \& Rein (1991) - A

Lin, Podell \& Rein (1991) - B

Matthew (1996) - A

Matthew (1996) - B

McArthur, Haynes, Malouf, Harris

\& Owings (1990)

Mitchell \& Fox (2001)

Reinking \& Rickman (1990) - A

Reinking \& Rickman (1990) - B

Swanson \& Trahan (1992) - A

Swanson \& Trahan (1992) - B

Zhang \& Brooks (1995) - A

Zhang \& Brooks (1995) - B

* significant at 0.05 level

** significant at 0.01 level $\begin{array}{llll}0.322 & -0.239 \text { to } 0.882 & 1.125 & 0.260 \\ 0.123 & -0.576 \text { to } 0.821 & 0.344 & 0.731\end{array}$

$\begin{array}{llll}0.610 & -0.105 \text { to } 1.325 & 1.673 & 0.094\end{array}$

$\begin{array}{llll}0.487 & -0.042 \text { to } 1.016 & 1.804 & 0.071\end{array}$

$\begin{array}{llll}-0.020 & -0.860 \text { to } 0.819 & -0.047 & 0.963\end{array}$

$1.251 \quad 0.326$ to $2.175 \quad 2.651 \quad 0.008 * *$

$\begin{array}{llll}0.470 & -0.382 \text { to } 1.322 & 1.082 & 0.279\end{array}$

$\begin{array}{llll}-0.165 & -0.723 \text { to } 0.393 & -0.580 & 0.562\end{array}$

$\begin{array}{llll}-0.450 & -1.033 \text { to } 0.133 & -1.513 & 0.130\end{array}$

$\begin{array}{llll}-0.324 & -0.778 \text { to } 0.130 & -1.397 & 0.162\end{array}$

$\begin{array}{llll}0.545 & 0.086 \text { to } 1.005 & 2.326 & 0.020 *\end{array}$

$\begin{array}{llll}0.387 & -0.199 \text { to } 0.973 & 1.294 & 0.196\end{array}$

$\begin{array}{llll}-0.604 & -1.173 \text { to }-0.034 & -2.079 & 0.038 *\end{array}$

$0.925 \quad 0.399$ to $1.451 \quad 3.445 \quad 0.001 * *$

$\begin{array}{llll}0.168 & -0.333 \text { to } 0.668 & 0.657 & 0.511\end{array}$

$\begin{array}{llll}-0.267 & -0.966 \text { to } 0.433 & -0.747 & 0.455\end{array}$

$\begin{array}{llll}0.639 & -0.076 \text { to } 1.354 & 1.753 & 0.080\end{array}$

$\begin{array}{llll}0.610 & -0.214 \text { to } 1.434 & 1.451 & 0.147\end{array}$

$2.740 \quad 1.599$ to $3.881 \quad 4.707 \quad 0.000 * *$ 
Table 2

Moderator Variables for each Individual Study

\begin{tabular}{|c|c|c|c|c|c|}
\hline Study name & $\begin{array}{l}\text { Systematic } \\
\text { Review }\end{array}$ & $\begin{array}{c}\text { Training } \\
\& \\
\text { Support }\end{array}$ & $\begin{array}{l}\text { Implementation } \\
\text { Fidelity }\end{array}$ & $\begin{array}{c}\text { Teacher } \\
\text { vs } \\
\text { Researcher }\end{array}$ & $N$ \\
\hline Chiang (1978) & Slavin (2008) & 3 & 1 & Teacher & 168 \\
\hline Hagerman (2003) & Slavin (2008) & 2 & 0 & Teacher & 121 \\
\hline Hunter (1994) & Slavin (2008) & 2 & 1 & Teacher & 270 \\
\hline Liston (1991) & Slavin (2008) & 0 & 0 & Teacher & 4597 \\
\hline Ross \& Nunnery (2005) & Slavin (2008) & 1 & 0 & Teacher & 3230 \\
\hline $\begin{array}{l}\text { Ross, Nunnery, Avis \& } \\
\text { Borek (2005) }\end{array}$ & Slavin (2008) & 0 & 0 & Teacher & 4085 \\
\hline Abraham (1984) & Slavin (2009) & 1 & 0 & Teacher & 103 \\
\hline Beasley (1989) & Slavin (2009) & 3 & 0 & Teacher & 74 \\
\hline $\begin{array}{l}\text { Campuzano, Dynarski, } \\
\text { Agodini \& Rall (2009) - A }\end{array}$ & Slavin (2009) & 3 & 1 & Teacher & 742 \\
\hline $\begin{array}{l}\text { Campuzano, Dynarski, } \\
\text { Agodini \& Rall (2009) - B }\end{array}$ & Slavin (2009) & 3 & 1 & Teacher & 1079 \\
\hline $\begin{array}{l}\text { Campuzano, Dynarski, } \\
\text { Agodini \& Rall (2009) - C }\end{array}$ & Slavin (2009) & 3 & 1 & Teacher & 618 \\
\hline $\begin{array}{l}\text { Campuzano, Dynarski, } \\
\text { Agodini \& Rall (2009) - D }\end{array}$ & Slavin (2009) & 3 & 1 & Teacher & 1155 \\
\hline Cassidy \& Smith (2005) & Slavin (2009) & 2 & 1 & Teacher & 93 \\
\hline $\begin{array}{l}\text { Chambers, Cheung, Madden, } \\
\text { Slaving \& Gifford (2006) }\end{array}$ & Slavin (2009) & 0 & 0 & Teacher & 394 \\
\hline $\begin{array}{l}\text { Chambers, Slavin, Madden, } \\
\text { Abrami, Tucker, Cheung \& } \\
\text { Gifford (2008) }\end{array}$ & Slavin (2009) & 1 & 1 & Teacher & 159 \\
\hline Collis, Ollila \& Ollila (1990) & Slavin (2009) & 0 & 0 & Teacher & 97 \\
\hline Erdner, Guy \& Bush (1998) & Slavin (2009) & 0 & 0 & Teacher & 85 \\
\hline $\begin{array}{l}\text { Macaruso, Hook \& McCabe } \\
\text { (2006) }\end{array}$ & Slavin (2009) & 1 & 0 & Teacher & 179 \\
\hline
\end{tabular}


Beringer, Abbott, Rogan,

Reed, Abbott, Brooks,

Vaughan \& Graham (1998) -

A

Beringer, Abbott, Rogan,

Reed, Abbott, Brooks,

Vaughan \& Graham (1998) -

B

Golden, Gersten \&

Woodward, (1990) - A

Golden, Gersten \&

Woodward, (1990) - B

Heise, Papalewis \& Tanner (1991)

Jinkerson \& Baggett (1993)

Jones (1994) - A

Jones (1994) - B

Lin, Podell \& Rein (1991) -

A

Lin, Podell \& Rein (1991) -

B

Matthew (1996) - A

Matthew (1996) - B

McArthur, Haynes, Malouf, Harris \& Owings (1990)

Mitchell \& Fox (2001)

Reinking \& Rickman (1990)

- A

Reinking \& Rickman (1990)

- B

Swanson \& Trahan (1992) -

A

Swanson \& Trahan (1992) -

B

Zhang \& Brooks (1995) - A

Zhang \& Brooks (1995) - B
Torgerson \&

Zhu (2003)

Torgerson \&

Zhu (2003)

Torgerson \&

Zhu (2003)

Torgerson \&

Zhu (2003)

Torgerson \& Zhu (2003

Torgerson \& Zhu (2003)

Torgerson \& Zhu (2003)

Torgerson \& Zhu (2003)

Torgerson \& Zhu (2003)

Torgerson \& Zhu (2003)

Torgerson \& Zhu (2003)

Torgerson \& Zhu (2003)

Torgerson \& Zhu (2003)

Torgerson \& Zhu (2003)

Torgerson \& Zhu (2003)

Torgerson \& Zhu (2003)

Torgerson \& Zhu (2003)

Torgerson \& Zhu (2003)

Torgerson \& Zhu (2003)

Torgerson \& Zhu (2003)
1

Teacher

48

Teacher $\quad 48$

Researcher 30

Researcher 30

Teacher

Researcher 20

Teacher 20

Teacher $\quad 20$

Researcher $\quad 48$

Researcher 45

Researcher $\quad 74$

Researcher $\quad 74$

Teacher $\quad 44$

Teacher $\quad 48$

Researcher $\quad 60$

Researcher $\quad 60$

Researcher $\quad 30$

Researcher $\quad 30$

Teacher $\quad 22$

Teacher 22 
Figure 1

Funnel Plot: Effect Size by Sample Size

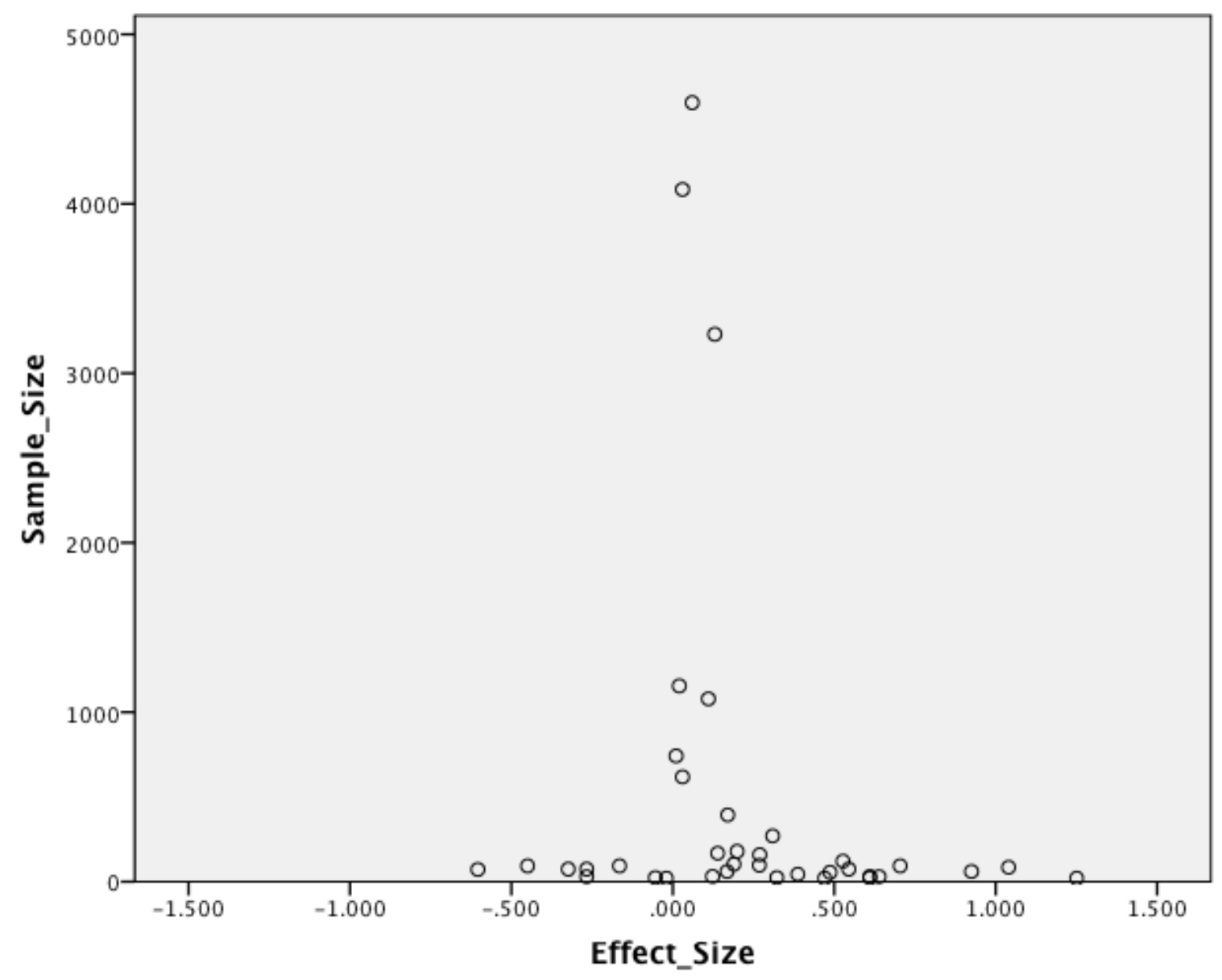




\section{Appendix A}

Full description of computer-assisted instruction studies

\begin{tabular}{|c|c|c|c|c|}
\hline $\begin{array}{c}\text { Systematic } \\
\text { Review }\end{array}$ & Study & Description & $\begin{array}{c}\text { Sample } \\
\text { Size }\end{array}$ & Inclusion \\
\hline $\begin{array}{l}\text { Slavin, } \\
2008\end{array}$ & Chiang (1978) & $\begin{array}{l}\text { Tested ASSIST, a teacher- } \\
\text { controlled computer assisted } \\
\text { instruction system in special } \\
\text { education. }\end{array}$ & 168 & Included \\
\hline $\begin{array}{l}\text { Slavin, } \\
2008\end{array}$ & $\begin{array}{l}\text { Hagerman } \\
(2003)\end{array}$ & $\begin{array}{l}\text { Evaluated the effectiveness of the } \\
\text { Accelerated Reader program } \\
\text { when used as a supplement to } \\
\text { teacher-directed instruction. }\end{array}$ & 121 & Included \\
\hline $\begin{array}{l}\text { Slavin, } \\
2008\end{array}$ & Hunter (1994) & $\begin{array}{l}\text { Evaluated the effect of the } \\
\text { Jostens Learning System for } \\
\text { improving the reading and } \\
\text { mathematical achievement levels } \\
\text { of Chapter One students in grades } \\
2 \text { through } 8 .\end{array}$ & 270 & Included \\
\hline $\begin{array}{l}\text { Slavin, } \\
2008\end{array}$ & Liston (1991) & $\begin{array}{l}\text { Assessed remedial } 10^{\text {th }} \text { grader's } \\
\text { use of Computer Curriculum } \\
\text { Corporation's integrated learning } \\
\text { system for reading skills. }\end{array}$ & 4597 & Included \\
\hline $\begin{array}{l}\text { Slavin, } \\
2008\end{array}$ & $\begin{array}{l}\text { Metrics } \\
\text { Associates } \\
(1981) \\
\end{array}$ & $\begin{array}{l}\text { Evaluated the use of } \\
\text { supplemental CAI programs. (ES } \\
=0.56)\end{array}$ & 105 & Excluded \\
\hline $\begin{array}{l}\text { Slavin, } \\
2008\end{array}$ & $\begin{array}{l}\text { Ross \& Nunnery } \\
\text { (2005) }\end{array}$ & $\begin{array}{l}\text { Compared the achievement of } 23 \\
\text { schools implementing School } \\
\text { Renaissance (SR) to those of } \\
\text { students in matched control } \\
\text { schools. }\end{array}$ & 3230 & Included \\
\hline $\begin{array}{l}\text { Slavin, } \\
2008\end{array}$ & $\begin{array}{l}\text { Ross, Nunnery, } \\
\text { Avis \& Borek } \\
\text { (2005) }\end{array}$ & $\begin{array}{l}\text { Compared the achievement of } 23 \\
\text { schools implementing School } \\
\text { Renaissance (SR) to those of } \\
\text { students in matched control } \\
\text { schools. }\end{array}$ & 4085 & Included \\
\hline $\begin{array}{l}\text { Slavin, } \\
2008\end{array}$ & Roy (1993) & $\begin{array}{l}\text { Evaluated the Jostens integrated } \\
\text { learning system in a junior high } \\
\text { and middle school. } \\
(E S=0.15)\end{array}$ & 408 & Excluded \\
\hline $\begin{array}{l}\text { Slavin, } \\
2009\end{array}$ & Abraham (1984) & $\begin{array}{l}\text { Measured the effect of computer- } \\
\text { assisted computation and phonics } \\
\text { drill and practice on first grade } \\
\text { reading and mathematics } \\
\text { achievement. }\end{array}$ & 103 & Included \\
\hline
\end{tabular}




\begin{tabular}{|c|c|c|c|c|}
\hline $\begin{array}{l}\text { Slavin, } \\
2009\end{array}$ & Beasley (1989) & $\begin{array}{l}\text { Examined the effects of the } \\
\text { writing to read computer-based } \\
\text { language arts program on first- } \\
\text { grade students' reading, writing, } \\
\text { and spelling achievement. }\end{array}$ & 74 & Included \\
\hline $\begin{array}{l}\text { Slavin, } \\
2009\end{array}$ & $\begin{array}{l}\text { Campuzano, } \\
\text { Dynarski, } \\
\text { Agodini \& Rall } \\
\text { (2009) - A }\end{array}$ & $\begin{array}{l}\text { Examined the use of a variety of } \\
\text { computer products in the } \\
\text { classroom to assist with reading } \\
\text { and mathematics learning. - A } \\
\text { (destination reading) }\end{array}$ & 1079 & Included \\
\hline $\begin{array}{l}\text { Slavin, } \\
2009\end{array}$ & $\begin{array}{l}\text { Campuzano, } \\
\text { Dynarski, } \\
\text { Agodini \& Rall } \\
\text { (2009) - B }\end{array}$ & $\begin{array}{l}\text { Examined the use of a variety of } \\
\text { computer products in the } \\
\text { classroom to assist with reading } \\
\text { and mathematics learning. - B } \\
\text { (headsprout) }\end{array}$ & 742 & Included \\
\hline $\begin{array}{l}\text { Slavin, } \\
2009\end{array}$ & $\begin{array}{l}\text { Campuzano, } \\
\text { Dynarski, } \\
\text { Agodini \& Rall } \\
(2009) \text { - C }\end{array}$ & $\begin{array}{l}\text { Examined the use of a variety of } \\
\text { computer products in the } \\
\text { classroom to assist with reading } \\
\text { and mathematics learning. - C } \\
\text { (plato focus) }\end{array}$ & 618 & Included \\
\hline $\begin{array}{l}\text { Slavin, } \\
2009\end{array}$ & $\begin{array}{l}\text { Campuzano, } \\
\text { Dynarski, } \\
\text { Agodini \& Rall } \\
(2009) \text { - D }\end{array}$ & $\begin{array}{l}\text { Examined the use of a variety of } \\
\text { computer products in the } \\
\text { classroom to assist with reading } \\
\text { and mathematics learning. - D } \\
\text { (Waterford early reading } \\
\text { program) }\end{array}$ & 1155 & Included \\
\hline $\begin{array}{l}\text { Slavin, } \\
2009\end{array}$ & $\begin{array}{l}\text { Cassidy \& } \\
\text { Smith (2005) }\end{array}$ & $\begin{array}{l}\text { Examined the effects of the } \\
\text { Waterford Early Reading } \\
\text { Program on reading achievement } \\
\text { gains across the first-grade year. }\end{array}$ & 93 & Included \\
\hline $\begin{array}{l}\text { Slavin, } \\
2009\end{array}$ & $\begin{array}{l}\text { Chambers, } \\
\text { Cheung, } \\
\text { Madden, } \\
\text { Slaving \& } \\
\text { Gifford (2006) } \\
\end{array}$ & $\begin{array}{l}\text { Examined the use of embedded } \\
\text { video multimedia in 1st graders } \\
\text { who learned beginning reading } \\
\text { through the "Success for All" } \\
\text { program. }\end{array}$ & 394 & Included \\
\hline $\begin{array}{l}\text { Slavin, } \\
2009\end{array}$ & $\begin{array}{l}\text { Chambers, } \\
\text { Slavin, Madden, } \\
\text { Abrami, Tucker, } \\
\text { Cheung \& } \\
\text { Gifford (2008) }\end{array}$ & $\begin{array}{l}\text { Examined the combined effects } \\
\text { of the Reading Reels embedded } \\
\text { multimedia content and the } \\
\text { Alphie's Alley computer-assisted } \\
\text { tutoring model. }\end{array}$ & 159 & Included \\
\hline $\begin{array}{l}\text { Slavin, } \\
2009\end{array}$ & $\begin{array}{l}\text { Collis, Ollila \& } \\
\text { Ollila (1990) }\end{array}$ & $\begin{array}{l}\text { Examined the impact of Writing } \\
\text { to Read (WTR) involving a } \\
\text { multisensory learning approach } \\
\text { including computers. }\end{array}$ & 97 & Included \\
\hline $\begin{array}{l}\text { Slavin, } \\
2009\end{array}$ & $\begin{array}{l}\text { Erdner, Guy \& } \\
\text { Bush (1998) }\end{array}$ & $\begin{array}{l}\text { Examined the effects of } \\
\text { computer-assisted instruction on }\end{array}$ & 85 & Included \\
\hline
\end{tabular}




\begin{tabular}{|c|c|c|c|c|}
\hline & & $\begin{array}{l}\text { the reading achievement of first } \\
\text { graders. }\end{array}$ & & \\
\hline $\begin{array}{c}\text { Slavin, } \\
2009\end{array}$ & $\begin{array}{l}\text { Macaruso, Hook } \\
\& \text { McCabe } \\
(2006)\end{array}$ & $\begin{array}{l}\text { Examined the use of CAI } \\
\text { programs designed by Lexia } \\
\text { Learning Systems to supplement } \\
\text { reading instruction. }\end{array}$ & 179 & Included \\
\hline $\begin{array}{l}\text { Slavin, } \\
2009\end{array}$ & RMC (2004) & $\begin{array}{l}\text { The literacy center (LeapFrog) } \\
(E S=-0.02)\end{array}$ & 195 & Excluded \\
\hline $\begin{array}{l}\text { Torgenson } \\
\text { \& Zhu } \\
(2003)\end{array}$ & $\begin{array}{l}\text { Beringer, } \\
\text { Abbott, Rogan, } \\
\text { Reed, Abbott, } \\
\text { Brooks, } \\
\text { Vaughan \& } \\
\text { Graham (1998) - } \\
\text { A }\end{array}$ & $\begin{array}{l}\text { Implemented training program to } \\
\text { teach children with handwriting } \\
\text { and/or spelling disabilities } 48 \\
\text { words and compared their use of } \\
\text { a pencil versus computer as a } \\
\text { response mode. - A (spelling } \\
\text { disabilities) }\end{array}$ & 24 & Included \\
\hline $\begin{array}{l}\text { Torgenson } \\
\text { \& Zhu } \\
(2003)\end{array}$ & $\begin{array}{l}\text { Beringer, } \\
\text { Abbott, Rogan, } \\
\text { Reed, Abbott, } \\
\text { Brooks, } \\
\text { Vaughan \& } \\
\text { Graham (1998) - } \\
\text { B } \\
\end{array}$ & $\begin{array}{l}\text { Implemented training program to } \\
\text { teach children with handwriting } \\
\text { and/or spelling disabilities } 48 \\
\text { words and compared their use of } \\
\text { a pencil versus computer as a } \\
\text { response mode. B (spelling and } \\
\text { handwriting disabilities) }\end{array}$ & 24 & Included \\
\hline $\begin{array}{l}\text { Torgenson } \\
\text { \& Zhu } \\
(2003)\end{array}$ & $\begin{array}{l}\text { Golden, Gersten } \\
\text { \& Woodward, } \\
\text { (1990) - A }\end{array}$ & $\begin{array}{l}\text { During reading comprehension } \\
\text { lessons a computer based instant } \\
\text { feedback system was compared } \\
\text { to a paper and pencil delayed } \\
\text { feedback system. - A (reading 1) }\end{array}$ & 31 & Included \\
\hline $\begin{array}{l}\text { Torgenson } \\
\text { \& Zhu } \\
(2003)\end{array}$ & $\begin{array}{l}\text { Golden, Gersten } \\
\text { \& Woodward, } \\
(1990) \text { - B }\end{array}$ & $\begin{array}{l}\text { During reading comprehension } \\
\text { lessons a computer based instant } \\
\text { feedback system was compared } \\
\text { to a paper and pencil delayed } \\
\text { feedback system. - B (reading 2) }\end{array}$ & 31 & Included \\
\hline $\begin{array}{l}\text { Torgenson } \\
\text { \& Zhu } \\
(2003)\end{array}$ & $\begin{array}{l}\text { Heise, } \\
\text { Papalewis \& } \\
\text { Tanner (1991) }\end{array}$ & $\begin{array}{l}\text { Compared computer assisted } \\
\text { Instruction (using software called } \\
\text { "Word Attack") to teacher } \\
\text { directed lessons for teaching } \\
\text { children reading and } \\
\text { comprehension. }\end{array}$ & 55 & Included \\
\hline $\begin{array}{l}\text { Torgenson } \\
\text { \& Zhu } \\
(2003)\end{array}$ & $\begin{array}{l}\text { Jinkerson \& } \\
\text { Baggett (1993) }\end{array}$ & $\begin{array}{l}\text { Compared the use of computer } \\
\text { "spell checker" in aiding students } \\
\text { to proofread and correct written } \\
\text { work versus making spelling } \\
\text { corrections by hand. }\end{array}$ & 20 & Included \\
\hline $\begin{array}{l}\text { Torgenson } \\
\text { \& Zhu } \\
(2003)\end{array}$ & Jones (1994) - A & $\begin{array}{l}\text { Examined the use of word } \\
\text { processors on the length and } \\
\text { quality of children's writing. - A }\end{array}$ & 20 & Included \\
\hline
\end{tabular}




\begin{tabular}{|c|c|c|c|c|}
\hline & & (writing 1) & & \\
\hline $\begin{array}{l}\text { Torgenson } \\
\text { \& Zhu } \\
\text { (2003) }\end{array}$ & Jones (1994) - B & $\begin{array}{l}\text { Examined the use of word } \\
\text { processors on the length and } \\
\text { quality of children's writing. - B } \\
\text { (writing 2) }\end{array}$ & 20 & Included \\
\hline $\begin{array}{l}\text { Torgenson } \\
\qquad \& \text { Zhu } \\
\text { (2003) }\end{array}$ & $\begin{array}{l}\text { Lin, Podell \& } \\
\text { Rein (1991) - A }\end{array}$ & $\begin{array}{l}\text { Compared Computer Assisted } \\
\text { Instruction to teacher-presented } \\
\text { paper-and-pencil material to see } \\
\text { how it impacts students' } \\
\text { performance on word } \\
\text { recognition. - A (non } \\
\text { handicapped) }\end{array}$ & 93 & Included \\
\hline $\begin{array}{l}\text { Torgenson } \\
\qquad \& \text { Zhu } \\
\text { (2003) }\end{array}$ & $\begin{array}{l}\text { Lin, Podell \& } \\
\text { Rein (1991) - B }\end{array}$ & $\begin{array}{l}\text { Compared Computer Assisted } \\
\text { Instruction to teacher-presented } \\
\text { paper-and-pencil material to see } \\
\text { how it impacts students' } \\
\text { performance on word } \\
\text { recognition. - B (handicapped) }\end{array}$ & 93 & Included \\
\hline $\begin{array}{l}\text { Torgenson } \\
\text { \& Zhu } \\
\text { (2003) }\end{array}$ & $\begin{array}{l}\text { Matthew (1996) } \\
\text { - A }\end{array}$ & $\begin{array}{l}\text { Reading comprehension and } \\
\text { attitudes toward reading of third- } \\
\text { grade students who read CD- } \\
\text { ROM interactive storybooks was } \\
\text { compared with those who read } \\
\text { traditional print storybooks. - A } \\
\text { (reading 1) }\end{array}$ & 74 & Included \\
\hline $\begin{array}{l}\text { Torgenson } \\
\text { \& Zhu } \\
(2003)\end{array}$ & $\begin{array}{l}\text { Matthew (1996) } \\
\text { - B }\end{array}$ & $\begin{array}{l}\text { Reading comprehension and } \\
\text { attitudes toward reading of third- } \\
\text { grade students who read CD- } \\
\text { ROM interactive storybooks was } \\
\text { compared with those who read } \\
\text { traditional print storybooks. - B } \\
\text { (reading 2) }\end{array}$ & 74 & Included \\
\hline $\begin{array}{l}\text { Torgenson } \\
\text { \& Zhu } \\
\text { (2003) }\end{array}$ & $\begin{array}{l}\text { McArthur, } \\
\text { Haynes, Malouf, } \\
\text { Harris \& } \\
\text { Owings (1990) }\end{array}$ & $\begin{array}{l}\text { Compared computer-assisted } \\
\text { instruction and paper-and-pencil } \\
\text { instruction for learning disabled } \\
\text { students in independent spelling } \\
\text { practice. }\end{array}$ & 44 & Included \\
\hline $\begin{array}{l}\text { Torgenson } \\
\text { \& Zhu } \\
\text { (2003) }\end{array}$ & $\begin{array}{l}\text { Mitchell \& Fox } \\
\text { (2001) }\end{array}$ & $\begin{array}{l}\text { Two computer programs } \\
\text { (DaisyQuest, Daisy's Castle) } \\
\text { were compared in how effective } \\
\text { they were in increasing } \\
\text { phonological awareness. }\end{array}$ & 72 & Included \\
\hline $\begin{array}{l}\text { Torgenson } \\
\text { \& Zhu } \\
(2003)\end{array}$ & $\begin{array}{l}\text { Reinking \& } \\
\text { Rickman (1990) } \\
\text { - A }\end{array}$ & $\begin{array}{l}\text { Compared comprehension from } \\
\text { reading passages on printed pages } \\
\text { accompanied by a dictionary or } \\
\text { glossary to reading passages on a }\end{array}$ & 60 & Included \\
\hline
\end{tabular}




\begin{tabular}{|c|c|c|c|c|}
\hline & & $\begin{array}{l}\text { computer screen that provided } \\
\text { assistance. }-\mathrm{A} \text { (vocabulary) }\end{array}$ & & \\
\hline $\begin{array}{l}\text { Torgenson } \\
\text { \& Zhu } \\
(2003)\end{array}$ & $\begin{array}{l}\text { Reinking \& } \\
\text { Rickman (1990) } \\
\text { - B }\end{array}$ & $\begin{array}{l}\text { Compared comprehension from } \\
\text { reading passages on printed pages } \\
\text { accompanied by a dictionary or } \\
\text { glossary to reading passages on a } \\
\text { computer screen that provided } \\
\text { assistance. - B (reading) }\end{array}$ & 60 & Included \\
\hline $\begin{array}{l}\text { Torgenson } \\
\text { \& Zhu } \\
(2003)\end{array}$ & $\begin{array}{l}\text { Swanson \& } \\
\text { Trahan (1992) - } \\
\text { A }\end{array}$ & $\begin{array}{l}\text { Examined the degree to which } \\
\text { computer assisted presentations } \\
\text { of text helped learning disabled } \\
\text { children's reading } \\
\text { comprehension. - A (learning } \\
\text { disabled readers) }\end{array}$ & 30 & Included \\
\hline $\begin{array}{l}\text { Torgenson } \\
\text { \& Zhu } \\
(2003)\end{array}$ & $\begin{array}{l}\text { Swanson \& } \\
\text { Trahan (1992) - } \\
\text { B }\end{array}$ & $\begin{array}{l}\text { Examined the degree to which } \\
\text { computer assisted presentations } \\
\text { of text helped learning disabled } \\
\text { children's reading } \\
\text { comprehension. - B (average } \\
\text { readers) }\end{array}$ & 30 & Included \\
\hline $\begin{array}{l}\text { Torgenson } \\
\text { \& Zhu } \\
(2003)\end{array}$ & $\begin{array}{l}\text { Zhang \& Brooks } \\
\text { (1995) - A }\end{array}$ & $\begin{array}{l}\text { Assessed the impact of } \\
\text { specifically designed computer } \\
\text { software tools on the quality of } \\
\text { the writing of children } \\
\text { performing at least one year } \\
\text { behind their school grade level as } \\
\text { judged by their classroom } \\
\text { teachers. - A (word processing) }\end{array}$ & 22 & Included \\
\hline $\begin{array}{l}\text { Torgenson } \\
\text { \& Zhu } \\
(2003)\end{array}$ & $\begin{array}{l}\text { Zhang \& Brooks } \\
\text { (1995) - B }\end{array}$ & $\begin{array}{l}\text { Assessed the impact of } \\
\text { specifically designed computer } \\
\text { software tools on the quality of } \\
\text { the writing of children } \\
\text { performing at least one year } \\
\text { behind their school grade level as } \\
\text { judged by their classroom } \\
\text { teachers. - B (speech synthesis) }\end{array}$ & 22 & Included \\
\hline
\end{tabular}

